Article

\title{
Research Trends in Pavement Management during the First Years of the 21st Century: A Bibliometric Analysis during the 2000-2013 Period
}

\author{
Heriberto Pérez-Acebo ${ }^{1, *(\mathbb{D})}$, Alaitz Linares-Unamunzaga ${ }^{2}$ (D) , Ricardo Abejón ${ }^{3}$ and \\ Eduardo Rojí ${ }^{4}$ \\ 1 Mechanical Engineering Department, University of the Basque Country UPV/EHU, \\ Po Rafael Moreno Pitxitxi, 2, 48013 Bilbao, Spain \\ 2 Department of Civil Engineering, University of Burgos, c/Villadiego, s/n, 09001 Burgos, Spain; \\ alinares@ubu.es \\ 3 Chemical and Biomolecular Engineering Department, University of Cantabria, Avda. Los Castros, s/n, \\ 39005 Santander, Spain; abejonr@unican.es \\ 4 Mechanical Engineering Department, University of the Basque Country UPV/EHU, Alda. Urquijo, s/n, \\ 48013 Bilbao, Spain; eduardo.roji@ehu.eus \\ * Correspondence: heriberto.perez@ehu.eus; Tel.: +34-94-601-7820
}

Received: 28 May 2018; Accepted: 20 June 2018; Published: 26 June 2018

\begin{abstract}
A bibliometric analysis based on Scopus database was carried out to identify the global research trends related to pavement management area from 2000 to 2013, and to improve the understanding of the research topics in that period. The results reveal two stable periods of annual publications, from 2000 to 2002 with an average rate of 27, and from 2003 to 2010 with a value of 51; and a period with an increasing production rate of 20 publications per year after 2010. According to the document-type distribution, articles and conference papers have almost the same contribution. The most productive country was the United States, followed by Canada and China. The research trend in the field of pavement management could be grouped into three main areas. The first one is related to pavement management systems, which attracted the greatest attention, especially optimization processes with various objectives and lifecycle cost analysis. The second group is about pavement performance modeling, where calibration of mechanical empirical models was largely developed. Lastly, data collection had also occupied several papers, mainly about cracking classification. Sustainability aspects in pavement management became an emergent issue. The trending issues in that period, in these categories, were summarized in the paper.
\end{abstract}

Keywords: pavement management; pavement management systems; bibliometric analysis; performance model; deterioration model; research trends; modeling; sustainability; International Roughness Index

\section{Introduction}

Due to an increasing transport demand, in the most developed countries, the construction of great road networks characterized the 20th century. Therefore, nowadays, the road agencies of these countries changed their main tasks, from projecting and constructing new infrastructures to managing and maintaining existing networks [1]. Other countries continue constructing new highways, but investment rates have decreased, compared with previous decades. Nevertheless, all of them have to expend a high percentage of their limited budgets on maintaining the road network in serviceable condition [2]. For example, real spending for highway investments in the United States was \$91 billion in 2013 [3]. Consequently, an efficient planning of road maintenance is the main goal of any highway administration, in order to plan maintenance activities according to the available funds. A pavement management 
system (PMS), defined as a systematic tool to manage, plan, and allocate budgets, and program all the pavement maintenance works, helps road agencies in the decision-making process [4]. Estimates stated that $\$ 101$ billion in annual capital investment, from 2008 to 2028 , would be needed to maintain all highways of the United States at present condition. Hence, every year, road networks get more deteriorated [3].

The amount of published papers about pavement management available in bibliography is huge, so basic managing devices are needed to handle all this information. Bibliometrics is a useful tool to map the literature around a research field. It refers to the research methodology employed in library and information sciences, which utilizes quantitative analysis and statistics methods to describe the distribution of patterns of publications according to some given categories, such as topic, field, source, author or country. These methods have been used to investigate research trends of specific fields recently [5-36]. The research publications of a country in certain scientific subfields can be considered as a reflection of its commitment to the state of science, despite some deficiencies. Firstly, many studies only select several journals or categories to represent global research trends related to a certain topic [37]. Secondly, the change in citations or publication counts of countries and organizations cannot completely indicate the development trend or future orientation of the research field [38]. More information, closely related to research itself, i.e., source title, author keyword, keyword plus, and abstracts, have also been introduced in the study of research trend [7].

The purpose of this study is to analyze, from a bibliometrical point of view, all the literature published in Scopus between 2000 and 2013 related to research on pavement management. These documents were analyzed and evaluated according to several criteria (publication year, document type, language, authors' institutions and countries, and keywords) and were employed to determine some quantitative characteristics of the research on the proposed theme, and identify the most relevant topics and trends in this field in that period.

\section{Data Sources and Methodology}

The data source was Scopus, with the abstract and indexing database with full-text links produced by Elsevier. Scopus claims to index over 21,500 titles from more than 5000 international publishers, stating that it is the "largest abstract and citation database of peer-reviewed literature" [39]. An independent and expert advisory board selects the list of titles indexed using strict criteria, based on user demand and market research.

It contains 38 million abstracts with references back to 1996. In addition to American journals, $60 \%$ of the covered titles are from countries other than the Unites States, highlighting European and Asian literature in English and other languages [40]. Therefore, Scopus covers a broad range of subjects and disciplines by the inclusion of thousands of journals in the life, health, physical, and social sciences. In order to improve search recall, in addition to keywords contributed by authors, extra index terms are manually added for most of the titles in the database, derived from thesauri that Elsevier owns or licenses.

For the bibliometric analysis, the online search within Scopus was carried out in April 2017 by the selection of "pavement management" as keywords in the article title, abstract, keywords fields of the search engine, in order to compile a complete bibliography with all the articles related to research on this topic, published during the period from 2000 to 2013. Different steps or evolution periods about the concept of pavement management have been identified. It is said that the term was born in the mid-1960s as an answer to the several unpredicted pavement failures in North America [41]. Some initiatives in the 1960s and the 1970s showed the necessity to measure pavement behavior in intermediate steps [41]. In the late 1970s, the pavement management systems were able to predict the maintenance needs for the entire highway network of the road agency [42]. In the 1980s, the World Bank introduced the vehicle operating costs in the lifecycle cost analysis by means of HDM-III [42]. In the 1990s, the introduction of personal computers completely changed the tools 
used in pavement management. The following step in pavement management evolution is aimed to be identified. With this aim, the final number of articles that were found in the period 2000-2013 was 727.

Research related to pavement management during the period 2000-2013 was analyzed, in detail, to provide a firm basis for a better understanding of the global research production, allowing identification of long-term strategies for this field. Therefore, the analyzed aspects covered not only the quantitative description of publications, including annual outputs, mainstream journals, language, Scopus categories, and leading countries and institutions, but also, the research tendencies obtained from author keywords in that period. This can give a global panorama of the research in the field of the pavement management during the first years of the XXI century.

\section{Results and Discussion}

\subsection{Bibliometric Analysis of Research on Pavement Management (2000-2013)}

\subsubsection{Publication Year, Document Type, and Language}

The distribution of annual publication output identified by Scopus is shown in Figure 1. The publication year of the documents shows the increasing attention (or not) that the subject is gaining in the research community. After the analysis of the figures, three different zones could be identified according to the annual production. The first one, from 2000 to 2002 , is characterized by a stable production rate with an average value of 27 publications per year. The next zone, started in 2003 and finished in 2010, shows a quite constant behavior, 51 publications/year, which nearly doubles the initial level. After 2010, there was a continuously increasing general trend in the number of publications that appeared each year. A linear regression was applied to the data, and the result was a very good fit, with an $R^{2}$ value of 0.987 . The assessed slope was 20 publications per year, a figure that gives an idea of the publication rate evolution.

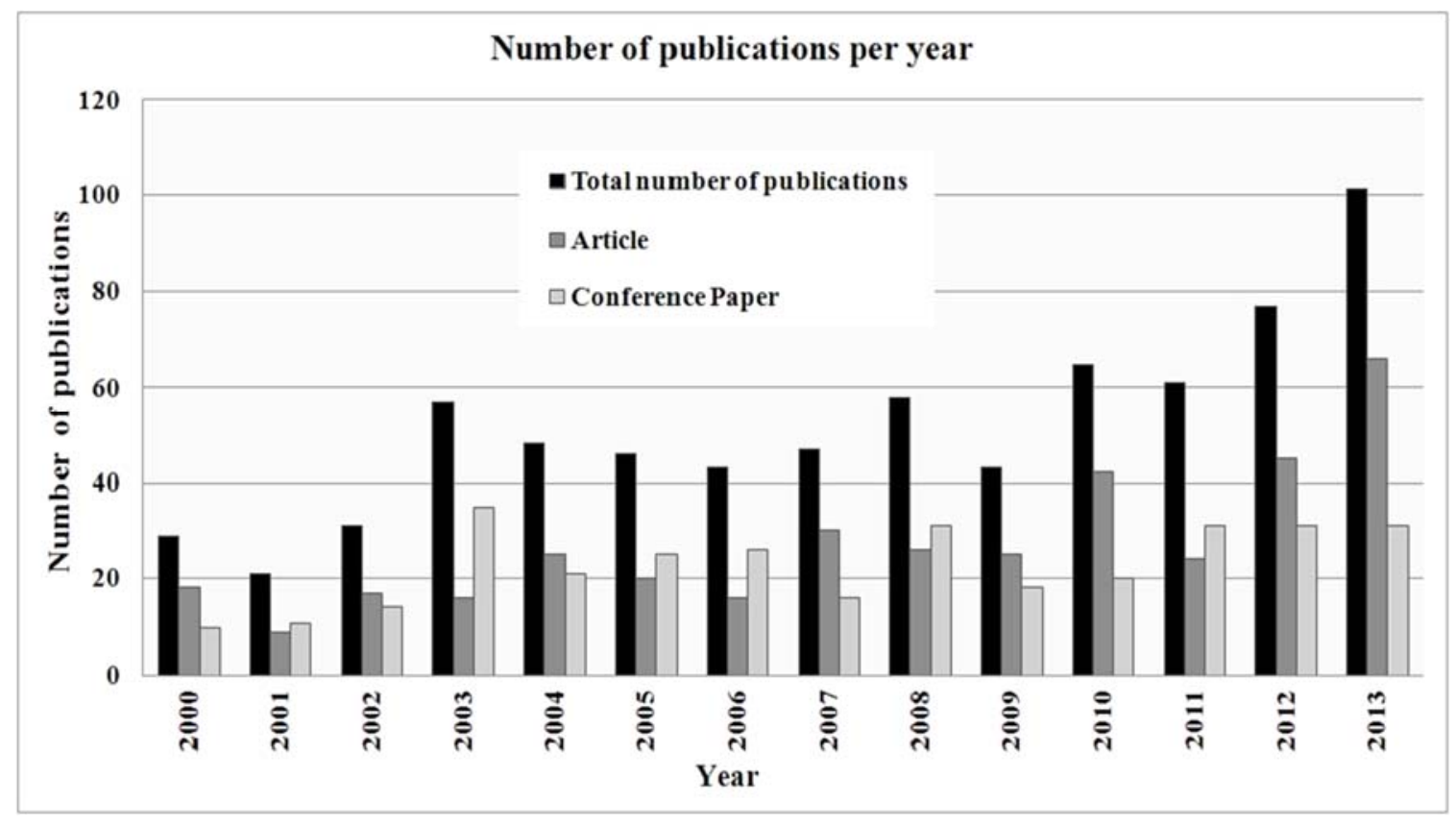

Figure 1. Annual publication output.

The distribution of document types was analyzed. It helps in understanding how innovation in this area is transmitted. Eight different document types were found among the 727 publications from the studied time range. Article (379) was the most frequently used document type, comprising $52.1 \%$ of the publications, followed by conference paper, with 320 documents ( $44.0 \%$ of the total production). 
The other less significant categories, whose joint contribution was lower than $4 \%$, included review (16), conference review (6), editorial (3), book (1), book chapter (1), and short survey (1). These percentages were not too concordant with the figures obtained by other bibliometric studies that demonstrated the clear supremacy of articles over other types of publication in other engineering areas, such as environmental or chemical engineering [43-45].

The singularity of the high importance of the conference papers in this study was more deeply analyzed. The breakdown of the annual production of both main document types is shown in Figure 1. As observed, the contribution of the conference papers was so important that it became the most frequent document type for several years: 2001, 2003, 2005, 2006, 2008, and 2011 (6 years in a 14-year period). This fact could be justified by the celebration, in these years, of some relevant international congresses and conferences, which greatly contributed to attain a high production of conference papers. Table 1 lists the most important congresses and conferences found in the Scopus database. However, not all the important and prestigious congresses or publications in the field of the pavement management, like the International Conference on Managing Pavement Assets, the European Pavement and Asset Management Conferences and the Conferences of the Australian Road Research Boards, are refereed, since they are not indexed in Scopus.

Table 1. The most important congresses and conference proceedings (with more than 5 documents).

\begin{tabular}{clcc}
\hline Ranking & & Documents & Percentage (\%) \\
\hline 1 & Geotechnical Special Publication & 17 & 2.3 \\
\hline 2 & Proceedings Annual Conference Canadian Society for Civil Engineering & 14 & 11 \\
\hline 3 & $\begin{array}{l}\text { Proceedings of the 1st Congress of the Transportation \& Development } \\
\text { Institute of ASCE }\end{array}$ & 10 & 1.5 \\
\hline 4 & $\begin{array}{l}\text { Proceedings International Conference on Applications of Advanced } \\
\text { Technologies in Transportation Engineering }\end{array}$ & 9 & 7 \\
\hline 5 & Proceedings of the 2013 Airfield and Highway Pavement Conference & 1.4 \\
\hline 6 & Proceedings of SPIE the International Society for Optical Engineering & 6 & 1.0 \\
\hline 7 & $\begin{array}{l}\text { Proceedings of the 2006 Airfield and Highway Pavement } \\
\text { Specialty Conference }\end{array}$ & \multirow{2}{*}{0.8} \\
\hline 8 & $\begin{array}{l}\text { 2010 Annual Conference and Exhibition of the Transportation } \\
\text { Association of Canada }\end{array}$ & 6.8 \\
\hline
\end{tabular}

The language of a publication area reflects the language chosen by researchers to transmit their knowledge. A clear majority of all the publications were published in English ( $96.1 \%$ of the documents). Only six other languages were found, with Chinese appearing as the second language, but with a very low contribution, as the papers written in this language only represented $2.8 \%$. The rest of languages were considered anecdotal: 5 documents in Spanish, 4 in French, and only 1 in Croatian, Korean, and Malay. It is obvious that English has been the main language employed for scientific research since some decades ago, and more specifically, in the engineering field [46-48]. Additionally, the majority of the bibliometric studies stated that above $95 \%$ of scientific publications were written in English $[49,50]$.

\subsubsection{Publication Distribution of Countries, Institutes and Authors}

The analysis of author's countries/territories was based on papers in which the address and affiliation of at least one author was provided. There were 16 papers without any author name (11) or address information (5), on Scopus. Therefore, the total number for distribution analysis of country publications was 711 . Among all the publications with author address, $628(88.3 \%)$ were single country publications, and $83(11.7 \%)$ were international collaborative publications.

Table 2 shows the top 20 countries ranked by the number of total publications with other information: the ranking and percentage of contribution according to single country or internationally collaborated papers, as well as first authors and corresponding authors. Some categories, like total 
publications or countries, are non-exclusive, so it is possible that some documents can be classified in more than one country simultaneously, as consequence of international collaborations. Therefore, the sum of the number of documents in these categories is above the total number of documents, and a similar result can be found in percentages, with results above $100 \%$. The existence of a reduced number of countries that dominate the publication of scientific documents was expected, as this pattern is very common in most scientific fields [51-53], including civil engineering $[54,55]$. The top 10 countries in Table 2 produced more than $85 \%$ of the total number of documents. The analysis demonstrated that the United States was the most productive country, with more than 340 documents $(48.9 \%)$ This leader country was followed by Canada ( 85 documents, $12.0 \%$ ) and China (69 documents, 9.7\%). These three countries had been previously identified among the top four contributors in the research fields related to civil engineering [54].

Table 2. The top 20 most productive countries.

\begin{tabular}{ccccccccccc}
\hline Country & $\mathbf{T P}^{\mathbf{1}}$ & $\mathbf{( \% )}^{\mathbf{1}}$ & $\mathbf{S P R}^{\mathbf{1}}$ & $\mathbf{( \% )}^{\mathbf{1}}$ & $\mathbf{C P R}^{\mathbf{1}}$ & $\mathbf{( \% )}^{\mathbf{1}}$ & $\mathbf{F P R}^{\mathbf{1}}$ & $\mathbf{( \% )}^{\mathbf{1}}$ & $\mathbf{R P R}^{\mathbf{1}}$ & $\mathbf{( \% )}^{\mathbf{1}}$ \\
\hline USA & 348 & $(48.9)$ & 1 & $(47.6)$ & 1 & $(59.0)$ & 1 & $(45.4)$ & 1 & $(46.3)$ \\
Canada & 85 & $(12.0)$ & 2 & $(11.5)$ & 2 & $(15.7)$ & 2 & $(11.5)$ & 2 & $(11.1)$ \\
China & 69 & $(9.7)$ & 3 & $(8.9)$ & 2 & $(15.7)$ & 3 & $(8.4)$ & 3 & $(8.6)$ \\
Taiwan & 24 & $(3.4)$ & 4 & $(3.7)$ & 22 & $(1.2)$ & 4 & $(3.2)$ & 4 & $(3.4)$ \\
Portugal & 23 & $(3.2)$ & 5 & $(2.9)$ & 8 & $(6.0)$ & 5 & $(2.8)$ & 5 & $(2.8)$ \\
South Korea & 19 & $(2.7)$ & 13 & $(1.0)$ & 2 & $(15.7)$ & 9 & $(1.7)$ & 11 & $(1.4)$ \\
Iran & 17 & $(2.4)$ & 7 & $(1.8)$ & 6 & $(7.2)$ & 6 & $(2.1)$ & 9 & $(1.7)$ \\
New Zealand & 17 & $(2.4)$ & 7 & $(1.8)$ & 6 & $(7.2)$ & 8 & $(1.8)$ & 6 & $(1.8)$ \\
Italy & 15 & $(2.1)$ & 7 & $(1.8)$ & 12 & $(4.8)$ & 9 & $(1.7)$ & 6 & $(1.8)$ \\
India & 13 & $(1.8)$ & 6 & $(2.1)$ & 37 & $(0.0)$ & 7 & $(2.0)$ & 6 & $(1.8)$ \\
Japan & 12 & $(1.7)$ & 16 & $(0.8)$ & 5 & $(8.4)$ & 12 & $(1.3)$ & 12 & $(1.3)$ \\
Australia & 12 & $(1.7)$ & 10 & $(1.6)$ & 18 & $(2.4)$ & 11 & $(1.4)$ & 10 & $(1.5)$ \\
Egypt & 10 & $(1.4)$ & 13 & $(1.0)$ & 12 & $(4.8)$ & 14 & $(1.1)$ & 16 & $(1.0)$ \\
Greece & 9 & $(1.3)$ & 11 & $(1.3)$ & 22 & $(1.2)$ & 14 & $(1.1)$ & 14 & $(1.1)$ \\
Singapore & 9 & $(1.3)$ & 11 & $(1.3)$ & 22 & $(1.2)$ & 12 & $(1.3)$ & 12 & $(1.3)$ \\
UK & 9 & $(1.3)$ & 19 & $(0.6)$ & 8 & $(6.0)$ & 17 & $(0.8)$ & 16 & $(1.0)$ \\
Palestine & 8 & $(1.1)$ & 19 & $(0.6)$ & 12 & $(4.8)$ & 16 & $(1.0)$ & 14 & $(1.1)$ \\
Chile & 6 & $(0.8)$ & 31 & $(0.2)$ & 8 & $(6.0)$ & 19 & $(0.7)$ & 23 & $(0.6)$ \\
Hungary & 6 & $(0.8)$ & 13 & $(1.0)$ & 37 & $(0.0)$ & 17 & $(0.8)$ & 18 & $(0.8)$ \\
Saudi Arabia & 6 & $(0.8)$ & 16 & $(0.8)$ & 22 & $(1.2)$ & 19 & $(0.7)$ & 18 & $(0.8)$ \\
\hline 1 TP: total publications; SPR: single country publication rank; CPR: international collaboration publication rank; \\
FPR: first author publication rank; RPR: corresponding author publication rank; (\%): percentage contribution to \\
the total.
\end{tabular}

The contribution of different institutions was estimated by the institution of affiliation of at least one author of the published papers. The top 13 institutions, the only ones which produced more than 10 documents, were ranked by their number of publications (Table 3). Among these institutions, 8 were American, 2 Canadian, and one each from China, Portugal and Taiwan. These five countries occupied the top five positions in the ranking of most productive countries. The leading organization was University of Waterloo, with 25 publications, followed by Universidade de Coimbra with 22 documents. Moreover, among the top 13 institutions, two private companies could be identified (Applied Research Associates Inc. (Albuquerque, NM, USA) from the United States, with 14 documents, and Stantec Inc. (Edmonton, AB, Canada) from Canada, with 12 publications), as well as a public institution from the United States (California Department of Transportation with 11 documents).

The nine most prolific authors in this research topic, who have published at least 10 documents, are shown in Table 4 . The total number of papers with author name was 716. Only the top two authors published more than 20 documents each about pavement management, S.L. Tighe and A.J.L. Ferreira, leading researchers of the most productive institutions, University of Waterloo and Universidad de Coimbra, respectively. The author in the 3rd position, R. Haas, was also affiliated to University of Waterloo. 
Table 3. The top productive institutions (with more than 10 publications).

\begin{tabular}{ccccc}
\hline Ranking & Institutions & Country & Documents & Percentage (\%) \\
\hline 1 & University of Waterloo & Canada & 25 & 3.4 \\
2 & Universidade de Coimbra & Portugal & 22 & 3.0 \\
3 & Texas A and M University & USA & 19 & 2.6 \\
4 & University of Texas at Austin & USA & 17 & 2.3 \\
5 & Tongji University & China & 17 & 2.3 \\
6 & Applied Research Associates Inc. & USA & 14 & 1.9 \\
7 & National Central University Taiwan & Taiwan & 13 & 1.8 \\
8 & Purdue University & USA & 12 & 1.7 \\
9 & Michigan State University & USA & 12 & 1.7 \\
10 & Stantec Inc. & Canada & 12 & 1.7 \\
11 & UC Berkeley & USA & 11 & 1.5 \\
12 & Virginia Polytechnic Inst. and State University & USA & 11 & 1.5 \\
13 & California Department of Transportation & USA & 11 & 1.5 \\
\hline
\end{tabular}

Table 4. The top nine most prolific authors.

\begin{tabular}{ccccc}
\hline Ranking & Author & Affiliation & Documents & Percentage (\%) \\
\hline 1 & Tighe, S.L. & University of Waterloo & 22 & 3.1 \\
2 & Ferreira, A.J.L. & Universidade de Coimbra & 20 & 2.8 \\
3 & Haas, R. & University of Waterloo & 11 & 1.5 \\
4 & Lin, J.D. & National Central University Taiwan & 11 & 1.5 \\
5 & Zhang, Z. & University of Texas at Austin & 10 & 1.4 \\
6 & Gunaratne, M. & University of South Florida Tampa & 10 & 1.4 \\
7 & Labi, S. & Purdue University & 10 & 1.4 \\
8 & Haider, S.W. & Michigan State University & 10 & 1.4 \\
9 & Madanat, S. & UC Berkeley & 10 & 1.4 \\
\hline
\end{tabular}

\subsubsection{Distribution of Output in Journals and Conferences}

The distribution of research subjects can be observed in Table 5, where the 10 most popular categories were compiled. Once again, the categories are non-exclusive, and a document can be related to more than one category, due to interdisciplinary research. The ranking indicated that Engineering was the clear dominant category, with a contribution percentage as high as $82.5 \%$. Social Sciences and Computer Science occupied the 2nd and 3rd positions, respectively. Out of these categories, none of the other subjects represented more than $5 \%$ contribution.

Table 5. The top 10 most popular subject categories.

\begin{tabular}{cccc}
\hline Ranking & Research Areas & Documents & Percentage (\%) \\
\hline 1 & Engineering & 600 & 82.5 \\
2 & Social Sciences & 132 & 18.2 \\
3 & Computer Science & 70 & 9.6 \\
4 & Earth and Planetary Sciences & 28 & 3.9 \\
5 & Environmental Science & 23 & 3.2 \\
6 & Materials Science & 20 & 2.8 \\
7 & Decision Sciences & 16 & 2.2 \\
8 & Mathematics & 14 & 1.9 \\
9 & Physics and Astronomy & 14 & 1.9 \\
10 & Business, Management and Accounting & 12 & 1.7 \\
\hline
\end{tabular}

The distribution of outputs in top 13 journals is shown in Table 6, with some data about those journals, like impact factors. The journal that appeared most frequently was Transportation Research Record, as more than 150 documents were published in this journal, which represented $20.9 \%$ of the total amount of papers. Journal of Transportation Engineering and Journal of Infrastructure Systems completed 
the podium of the top journals, and two specific journals about pavement, International Journal of Pavement Engineering and International Journal of Pavement Research and Technology, were situated in 4th and 5th positions, respectively.

Table 6. The top most productive journals.

\begin{tabular}{|c|c|c|c|c|c|}
\hline Ranking & Journal & Documents & Percentage $(\%)$ & IF (2016) & SJR (2016) \\
\hline 1 & Transportation Research Record & 152 & 20.9 & 0.522 & 0.557 \\
\hline 2 & Journal of Transportation Engineering & 58 & 8.0 & 0.962 & 0.774 \\
\hline 3 & Journal of Infrastructure Systems & 26 & 3.6 & 1.516 & 0.859 \\
\hline 4 & International Journal of Pavement Engineering & 21 & 2.9 & 1.832 & 0.824 \\
\hline 5 & International Journal of Pavement Research and Technology & 18 & 2.5 & - & 0.375 \\
\hline 6 & Advanced Materials Research & 16 & 2.2 & - & 0.120 \\
\hline 7 & Tongji Daxue Xuebao-Journal of Tongji University & 9 & 1.2 & - & 0.252 \\
\hline 8 & Better Roads & 9 & 1.2 & - & 0.100 \\
\hline 9 & Road and Transport Research & 7 & 1.0 & 0.021 & 0.175 \\
\hline 10 & Canadian Journal of Civil Engineering & 6 & 0.8 & 0.591 & 0.406 \\
\hline 11 & Computer Aided Civil and Infrastructure Eng. & 6 & 0.8 & 5.786 & 1.180 \\
\hline 12 & KSCE Journal of Civil Engineering & 6 & 0.8 & 0.812 & 0.360 \\
\hline 13 & Journal of Computing in Civil Engineering & 6 & 0.8 & 2.31 & 0.739 \\
\hline
\end{tabular}

In addition to the commented journals, several proceedings, corresponding to congresses and conferences celebrated during the analyzed time interval, contributed with more than 5 documents (Table 1). Their total contribution achieved was $11.0 \%$, while the contribution of the journals in Table 5 was $46.8 \%$. Therefore, more than $42 \%$ of the total found documents were not published in these leader journals and proceedings, a fact that demonstrated the great heterogeneity of bibliographic sources involved in the dissemination of the most recent research in pavement management.

\subsubsection{Distribution Analysis of Keywords}

The 30 most frequently used keywords appearing in the 727 considered documents are listed in Figure 2. The results indicated that "pavements" was the most relevant keyword, as it appeared in 483 papers (66.4\% of the total amount of articles). Besides, "pavement" was selected as keyword by 125 papers (17.2\%). Another pair of singular and plural forms appeared in Figure 2: "pavement management systems" appeared 212 times (3rd place) and "pavement management system" 72 times, implying a joint contribution of $39.1 \%$. The exact expression "pavement management", which was employed in the search engine, occupied the 2nd place (in 252 documents). Nevertheless, other highly related expressions, including the word "pavement", were employed as keywords with a high incidence: "pavement performance" (75 times), "pavement condition" (73), "concrete pavements" (60), "pavement maintenance" (58), "pavement overlays" (56), "flexible pavements" (53), or "asphalt pavements" (51). In addition, the analysis of the main keywords, which did not include the "pavement" word, supported the previously exposed idea: the improvement of the classical PMSs by incorporation of new optimization strategies to ensure a better planning and administration framework, as the presence of keywords such as "maintenance", "highway administration", "decision making", "mathematical models", or "optimization" demonstrated. A further and deeper comment of the most relevant research hot topics was carried out in the Section 3.2. 


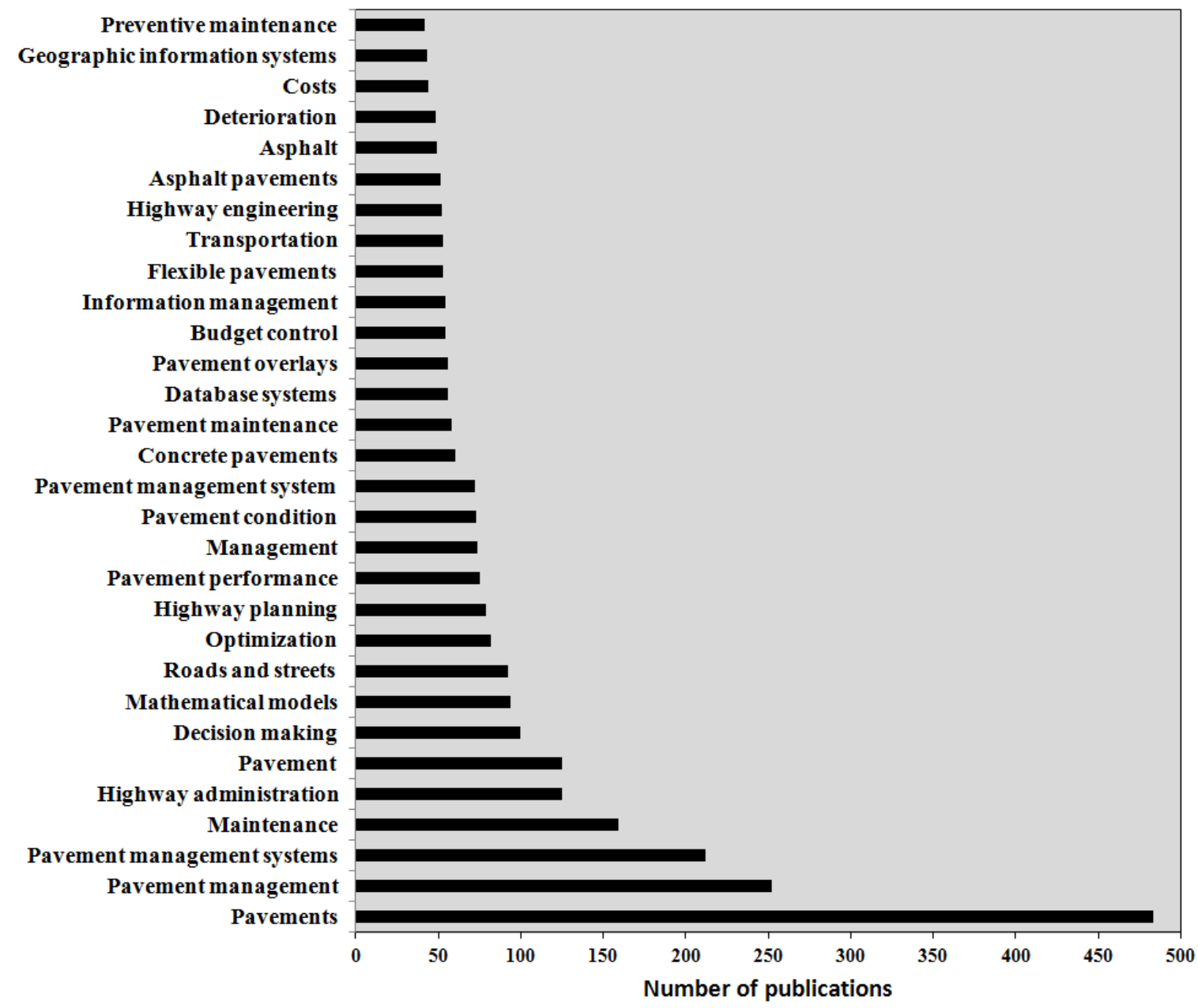

Figure 2. The top 30 most frequently used keywords from 2000 to 2013.

\subsection{Keywords and Trending Topics of the Research on Pavement Management}

As previously said, author keywords generalize the major attention of a research. Bibliometric method, through author keyword analysis in a specific period, has been developed in the last decade, and has proved to be a helpful method in revealing the research hotspots and discovering scientific research trends [5]. This time, in order to analyze, exclusively, the research trends in pavement management in the last years of studied period, where more papers were published, author keywords in the publications during the years 2012 and 2013 only have been assessed. The limitation about the years of publication was imposed to consider the state of art of the first years of the second decade of the 21st century. This way, the focus on the trends of 2012 and 2013 can give clues for the research directions at present, providing a review less biased by previous references of the first decade of the century.

Examination of author keyword in this study period revealed that 1.509 keywords were used. Among them, 1.126 (75\%) keywords appeared only once, and $212(14 \%)$ keywords appeared twice. Only $11 \%$ of all author keywords (171) were used more than three times. Table 7 shows the top 30 most frequently used author keywords appeared in articles of pavement management field during 2012 and 2013, with combinations of their plural forms, abbreviations and other semantic relations. For example, as all the keywords are related to pavements; keywords like "deterioration" and "pavement deterioration" have been considered together. Furthermore, expressions like "deterioration models" and "deterioration modelling" have been associated to the previous expressions, since all of them underline the same idea. 
Table 7. The top 20 most frequently used keywords during the 2012-2013 period.

\begin{tabular}{clc}
\hline Ranking & \multicolumn{1}{c}{ Keywords (Times Used Each Expression) } & Times Used \\
\hline 1 & Pavements (123) + Pavement (38) & 161 \\
2 & Pavement management systems (84) + Pavement management system (21) + PMS (4) & 109 \\
3 & Pavement management (70) + Management (30) & 100 \\
4 & Maintenance (43) + Pavement maintenance (20) & 63 \\
5 & Pavement condition (30) + Pavement condition indices (7) + Condition index (3) & 40 \\
6 & Optimization (28) + Optimization models (6) + optimizations (3) & 37 \\
7 & Pavement performance (30) + Deterministic pavement performance models (4) + & 36 \\
& Performance model (3) + Performance prediction (3) & 34 \\
8 & Deterioration (16) + Pavement deterioration (9) + Deterioration models (6) + & 29 \\
9 & Deterioration modeling (3) & 28 \\
10 & Decision making (14) + Decision making process (6) + Decision support systems (6) + & 26 \\
11 & Decision trees (3) & 26 \\
12 & Highway administration & 22 \\
13 & Life cycle (11) + Lifecycle costs (8) + Life-cycle costs (4) + Life-cycle cost analysis (3) & 18 \\
14 & Mathematical models (11) + Numerical model (11) & 18 \\
15 & Highway planning & 16 \\
16 & Design (14) + Pavement design (4) & 15 \\
17 & Glexible pavements & 15 \\
18 & Transportic algorithms (9) + Genetic algorithm (6) & 15 \\
19 & Maintenance and rehabilitations (6) + Pavement maintenance and rehabilitations (5) & 14 \\
20 & + Pavement maintenance and rehabilitation (4) & \\
\hline
\end{tabular}

As was expected after using "pavement management" as keywords in the article title, abstract, and keywords fields of the search engine, "pavement" (and its plural form) was the most relevant keyword, as it appeared 161 times in 178 papers (90.4\% of the total amount of articles), and "pavement management" (and "management") was selected as a keyword by 100 papers (56.2\%). Between them, the expressions "pavement management systems" (and its singular and its abbreviation, PMS) occupied the 2nd position in this rank, highlighting the importance of this set of systematic tools for assisting engineers in effectively and efficiently managing the road pavements. Nevertheless, other used keywords that were not in the top three helped to identify the research trends. Expressions like "maintenance" (4th position, 63 times), "optimization" and "optimization models" (ranked in 6th position), and "deterioration" (8th) support the idea of the improvement of classical pavement management systems by incorporating new optimization strategies to ensure a better planning of the maintenance and administration of the network. The employment of "pavement performance" and related words (7th position), and "mathematical models" (13th), as keywords, shows that efforts were made to improve the modeling of the pavement deterioration process. Finally, despite the data collection advances, pavement indices still attracted research attention, due to the 5th place of "pavement condition", or the presence of "International Roughness Index", a worldwide-utilized index in 20th position.

Based on these analyses, the research trend in the initial years of the 2010s in the field of pavement management can be divided in three categories: pavement data collection, pavement performance models, and pavement management systems. As stated before, with the aim of reviewing the last research tendencies in the mentioned period, publications from 2012 and 2013, which have oriented present research, are mainly highlighted. Therefore, the state-of-art of the last years of the studied time interval is more objectively described.

\subsubsection{Pavement Data Collection}

As all pavement roads deteriorate with time, mainly due to traffic loading and weather actions [56], consistent and repeatable data collection is an indispensable element of a PMS. Traditionally, manual surveys were conducted for data collection, which were time consuming and biased. Nonetheless, 
automated technologies for data collection were developed [57], being still an essential research area. Pavement condition can be divided in two groups: functional and structural. The functional condition of a pavement refers to the effectiveness in fulfilling its function of serviceability, shown by smooth and safe ride, sufficient capacity for demand, without bumps and high noise levels. By contrast, the structural condition assesses the load carrying capacity of the pavement during its life [58].

Pavement texture, defined as "the deviation of the pavement from a true planar surface" [59], is a key measure of pavement surface characteristics, as it is directly related to safety and comfort [60]. Macrotexture measurement attracted great research attention [61]. New macrotexture measurement systems, based on 3D technologies, have been tested, and provide accurate and repeatable data at usual highway speeds $[61,62]$. Similarly, a 3D pavement surface measurement tool was also introduced to collect rut data, the longitudinal depression that occurs in the wheel path, without interrupting the traffic [63].

When referring to road safety, the skid resistance is said to be a vital feature [60]. Recent research deals with finding a correlation between the skid number and the mean profile depth without interrupting traffic circulation [64], and to develop a 3D behavior model integrating skid resistance, travel speed, and wheel slip ratio [65]. Research also focused on skid resistance measurements on chip seals provided by three different tests [66], and the factors that best indicate the flushing occurrence, an area with low skid resistance that must be avoided [67].

Pavement distresses and cracking are evident signs of pavement deterioration. Measuring and mapping them has been challenging, due to their nature, location, and size. Traditionally, inspectors walking along the roadway section carried out detailed manual inspection surveys. As they were time consuming and expensive, they were substituted by automated distress survey methods, ranging from high-speed contactless laser sensors, to devices recording video images of pavement surface. Later, processing algorithms, usually based on neural networks, are employed to identify the types of cracks and other distresses. Usual problems are classification errors and long processing times [68]. Papers published at initial years of the 2010s offered new solutions to these problems. On one hand, new tools were proposed [69,70]. On the other hand, new algorithms were developed to process images [68,71-74]. Even a combination of both techniques was proposed [75].

Based on the results of the International Road Roughness carried out in Brazil in 1982 [76], the World Bank developed the International Roughness Index (IRI), and due to its stability over time and transferability throughout the world, it has become a recommended standard for road roughness or smoothness evaluation $[77,78]$. Instead of calculating IRI in a one-way vertical section, Wang et al. [79] proposed an automatic gadget using five laser probes to measure the whole cross section in urban roads.

The Pavement Condition Index (PCI) is a very common distress survey method deployed in the United States. Alternatives techniques were presented to predict the PCI, by means of artificial neuronal networks (ANN) and genetic programming [80] or a fuzzy logic-based system [81].

Pavement structural capacity evaluation indicates pavement remaining life, i.e., the quantity of load repetitions that it can still withstand. Structural capacity of a pavement takes into account the structural capacity of all the layers of the pavement, as well as the condition of the subgrade [82]. Pavement structural evaluation methods are usually divided into destructive and non-destructive tests. Among the non-destructive techniques, pavement deflection is currently the most widely employed. One of the deflection measurement devices employed is the Benkelman beam, also deployed to measure the full deflection basin on forest roads [83]. Another device is the falling weight deflectometer (FWD), whose results were adjusted utilizing different sources of temperature gradient data and models [84]. Nevertheless, as these tools need to interrupt the traffic to operate, their use at the network level is limited, alternative devices are introduced, especially the rolling wheel deflectometer (RWD), because it can measure at traffic speeds. In Louisiana, an acceptable repeatability of RWD measurements at different test speeds was demonstrated [85], and the RWD index was developed as a useful index for pavement structural condition assessment, but not for selection of the correct treatment [86]. 
The structural condition cannot be forecasted from surface condition data [87]. Therefore, different decisions are taken if only functional condition parameters are employed, or if deflection tests are included in the decision process [88]. Hence, the introduction of a structural capacity index is suggested in network-level decisions to find the most cost-effective rehabilitation option [89]. On this basis, simplified deflection-based analytical techniques [90] and a new index related to the Structural Capacity Index (SCI) [91] have been introduced.

Other new indices have been also proposed, like the pavement-assessment triangular model [92] or an index based on a visual evaluation of the conditions of road elements and pavement [93]. Besides these, normally employed indices were reconsidered to improve their calculation method, like the algorithm of the SCI [94], and the Pavement Condition Ratio (PCR) by means of fuzzy reasoning theories [95]. Finally, new methods for pavement segmentation have been also presented [96-98].

\subsubsection{Pavement Performance Models}

The pavement management includes developing models that are able to foresee the pavement performance over time. There is a wide range of pavement performance models, deployed by highway administrations to satisfy their needs. At network level, performance models are employed to estimate the future condition of the road network, and to establish M\&R works in both short and long term. In contrast, at project level, performance models help to estimate the best alternative of treatment with the best benefit-cost rate. Models are usually based on field observations at network level, and on mechanistic principles only or with in situ data at project level [77,78,99].

For the last 15 years, it can be stated that pavement design, especially in North America, has shifted from empirical approach to mechanistic-empirical (M-E) approach. M-E design upgrades empirical design methods by introducing mechanistic behavior, correlating recorded distresses to applied loads in the road structure [100]. The Mechanistic-Empirical Pavement Design Guide (MEPDG) was produced in 2004, principally thanks to the National Cooperative Highway Research Program (NCHRP) Project 1-37A [101], and subsequently delivered to the American Association of State Highway and Transportation Officials (AASHTO) [102]. The Mechanistic-Empirical Pavement Design Guide (MEPDG) [102] can be deployed for flexible and rigid pavement, and includes the most used pavement structures in North America, incorporating the theoretical analysis to field observations, in order to include the intricate consequences of traffic loading, climatic effects, and material aging on pavement distresses. Nevertheless, MEPDG performance models were developed and calibrated with the Long-Term Pavement Performance (LTPP) data [103] and, therefore, differences can be found when introducing "local" inputs, such as climate, material characteristics, traffic patterns or construction and M\&R methods. Therefore, suggested performance models should be checked and calibrated with local data, as many states of the United States carried out: North Carolina [104], California [105], Texas [106], and Washington [107]. Hence, apart from being employed for designing durable pavement sections, the MEPDG contributes to the pavement management providing reliable and consistent performance models, calibrated both nationally and locally.

A national guideline for local calibration, the Guide for the Local Calibration of the MechanisticEmpirical Pavement Design Guide [108], derived from NCHRP Project 1-40B [109], received considerable research attention. On this basis, the results from a local validation of rutting data recorded in the PMS of the Ministry of Transportation of Ontario (MTO) showed that a unique optimal solution could not be achieved because rutting models were imprecise [103]. A similar conclusion was reached in another study performed in Ontario [110], demonstrating that no new distress models were better than the existing PMS model of the MTO. Likewise, the verification of the MEPDG model for rutting in local conditions showed that the predictions were higher than observed rutting in Louisiana [111], and statistical analysis was then carried out [112]. In contrast, fatigue and International Roughness Index (IRI) models proposed in the MEPDG were concluded to be applicable in Louisiana [113] and in Tennessee [114]. However, some road administrations cannot calibrate the MEPDG models as required inputs are not available. Hence, Nassiri et al. [115] identified the significant inputs for an IRI model in 
Alberta (Canada). Moreover, the Pavement Management Guide [4], published in 2012, proposed the performance models shown in the MEPDG, and expects more accurate models as the models become calibrated in more states and countries.

Despite the improvement achieved from upgrading the purely empirical design methods, M-E methods must still deal with some uncertainty when estimating pavement behavior. To address this problem, different solutions were suggested, like uncertainty management, that considers variability of the parameters and model uncertainty [100], and a new model that combines two different mechanistic theories [116].

Pavement deterioration models can also be defined as deterministic or probabilistic [77,117-119]. Among probabilistic models, the Markov chains received great attention in the studied time interval [120]. It can be applied to any index or parameter, like the Pavement Condition Index (PCI) [121]. To obtain the Markovian transition probabilities, historical data have been deployed, if available, or the knowledge of experienced engineers [78]. When using a TPM obtained from experts' knowledge, it can be updated as soon as field data become available by means of a Bayesian approach [122]. For incomplete in situ observation data, the use of the exponential hidden Markov model has been suggested [123]. In addition, a semi-Markov model, without the "memoryless" property of Markov models, has been presented, where the sojourn time in each condition follows a Weibull distribution [124].

Nonetheless, there is no consensus on techniques for performance modeling because of the wide range of factors that must be considered, and the limitations and accuracy of field data. Consequently, researchers are exploring alternative methods, such as polynomial functions [125], and truncated Levy flight distribution [126]. Regression analyses were employed for various purposes: for macrotexture prediction in chip seals [127], for generalized models in Louisiana [128], and a multilinear regression for IRI and rutting modeling [129]. ANN has been deployed for Present Serviceability Index (PSI) of urban flexible pavements [130] and for cracking, raveling, rutting, and roughness for secondary roads in India [131]. Feed forward neural networks modeling method was used to forecast gravel loss in gravel roads in Botswana [132]. Flexible pavement rehabilitation treatments have been evaluated by means of aggregate and disaggregate post treatment performance models [133]. In case of limited or incomplete data, an autoregression method [134] or a hybrid technique [99] were suggested.

Moreover, since 1968, the World Bank has conducted a series of projects about roads, and has developed various evaluation modules that include pavement performance models. They were distributed to more than 100 countries around the world, and they need to be adapted to local conditions, as performed in India [135]. The HDM-4 model for cracking performance, developed by the World Bank, has been incorporated to a new Portuguese maintenance optimization system [136]. Other models, derived from HDM-4, have substituted previously used AASHTO performance models in Visseau (Portugal) [137]. Finally, performance model idea has been exported to other fields, like paint pavement markings [138].

\subsubsection{Development of New Pavement Management Systems and Sustainability}

A PMS is defined as a set of techniques and methods that provide support to road agencies in order to allocate limited resources optimally while maintaining the road networks in the level of service demanded by users. As a consequence, use of optimization techniques for pavement management has increased in the last few decades, due to more limited budgets, increasing demands, and stricter responsibility in infrastructure allocation [139].

In general, optimization tools applied in pavement management can be classified into single-objective or multi-objective optimization. Single-objective optimization follows different targets, such as to minimize cost or maximize the treatment benefits in terms of pavement's condition or life [140]. Nonetheless, it is not recommended to make a decision according to a sole criterion, especially in road management, where more than one goal must be taken into account. On the contrary, multi-objective optimization attempts to find an optimal solution satisfying various restrictions and 
optimizing some objective functions. Therefore, the research on pavement management become an appropriate area for developing the multi-objective optimization methods, confirmed by the keywords "optimization" and related words (6th position in Table 6), "decision making" (9th), or "genetic algorithm(s)" (17th).

In the pavement management field, diverse methods have been applied in the current century to solve multi-objective optimization problems with varying success. Examples of applied techniques in the period 2012-2013 are the weighting sum method [141], compromising programming [142], analytic hierarchy process [143], the parametric method [144], and genetic or evolutionary algorithms [145-147]. Sometimes, two methods are combined to solve an optimization, such as the generic algorithm and the weighting sum method [104,105], or the genetic algorithm and goal programming [148].

Optimization has been also utilized to allocate resources between competing elements of highway asset management too, such as pavement and bridge deck maintenance [1], heterogeneous infrastructure systems [149], or between various programs, like pavement improvement and capacity expansion of the road [150]. Moreover, some researchers have exported the idea of PMSs to other infrastructures, usually not analyzed, like median and sidewalks [151], road segments in landfills [152], and parking [153].

The World Bank, as explained in Section 3.2.2., has developed several evaluation modules to combine technical and economic appraisals of road projects, in order to prepare road investment programs and to analyze road network strategies. The last version, HDM-4 (Highway Development \& Management) still provided advanced highway investment evaluation tools [154], which were calibrated in Malaysia [155] and in Taiwan [156].

At the project level of PMSs, decisions are targeted to define the projects with the best cost-benefit ratio, so the limited budgets are used to construct, maintain, or rehabilitate longer lasting roads, considering all the road-life [157]. Accordingly, the concept of lifecycle cost analysis (LCCA) is highlighted during the project-level analysis. LCCA, born in the United States, is utilized to evaluate competing alternatives that take into account all related significant costs, e.g., construction, maintenance, and operations, over the life analysis period, and has become the most successful technique worldwide [2,158]. LCCA received increasing attention as a methodology to help road agencies in order to make economical investment decisions, (11th position in Table 6). Researchers developed advanced models to conveniently assist the decision-making process. Hence, some new models were proposed, such as OPTIVAV, which calculates all the costs and the value of the road after its service-life [159], and is a method for selecting the best chip seal treatment option based on LCCA analysis [160], and a hybrid technique that considers thresholds in management [161]. A discount rate must be applied in LCCA, and it can significantly influence the decision. Hence, the impact of the discount rate in a new LCCA system was analyzed [162]. Furthermore, the right moment for conducting M\&R activities is a vital factor of the LCCA, and, therefore, consequences of postponing treatments have been quantified [163], and a tool that indicates the correct moment and extension of the road to be repaired is presented [164].

Nonetheless, the transportation sector has an extraordinary impact on climate change policy [165]. Nevertheless, most of the efforts for greenhouse gas (GHG) emissions reduction were focused on vehicle technologies and alternative fuel options [166], and PMSs have not taken into account environmental parameters $[167,168]$. However, this trend was shifted during the first years of the 21st century, and sustainability and environmental factors emerged as key factors in PMS strategies [169], as the amount of papers, in that period, about this topic, certifies [170-177].

Additionally, the reduction of the energy consumed and resulting GHG emissions from M\&R activities are specifically being incorporated to PMSs, introducing it as a new goal in multi-objective optimization [178,179], or as a third step in new three-stage optimization methodology [180].

Lastly, new technologies are introduced in the field of PMSs, like application of iPad [181] or using the Google public cloud [182]. 


\section{Conclusions}

An overview of the research on pavement management during the first 14 years of the 21st century was presented, with the information related to annual publications, document types, languages, countries, institutions, authors, categories, journals, and research emphases and tendencies. The identification of the hot topics could provide a clue to research institutions or universities to evaluate the past research attention, and what kind of projects they were supporting and financing. The number of publications about this subject was characterized by a stable production rate in two periods, the 2000-2002 period, with an average value of 27, and the 2003-2010 period, with an average value of 51. After 2010, it can be stated that the production is incremented by 20 publications per year. The document distribution showed a variety of types, specifically, the article (52.1\% of the publications) and the conference paper $(44.0 \%)$, were the most frequently used documents, differing from other research tendencies in other engineering areas. Nevertheless, not all the international and fundamental congresses about pavement management as the International Conference on Managing Pavement Assets and the European Pavement and Asset Management Conferences are included, as they are not indexed in the Scopus database. The United States appears as the leading country in total number of publications, followed by Canada and China. The leading organizations were University of Waterloo (Canada) and Universidade de Coimbra (Portugal). Among the 13 top institutions, there are two private companies, Applied Research Associates Inc. (Albuquerque, NM, USA) and Stantec Inc. (Edmonton, AB, Canada) and a public institution, California Department of Transportation (USA).

The proposed analysis by keywords of articles published in years 2012 and 2013, within the Scopus search engine, provided the clues for the identification of hot research issues in the final years of the studied period. Pavement management systems was by far the most investigated area, mainly obliged by the lower and lower budgets for pavement maintenance and rehabilitation. Principally, more modern optimization models, such as multi-objective ones, were applied to optimally allocate limited resources, with genetic algorithms receiving the greatest attention. At network level, maintenance strategies over the entire road network were discussed, aiming to take the most value of the spent money, and establish the best moment to carry out the activities. At project level, the construction, maintenance, and operational costs were taken into account, and lifecycle cost analysis was widely used to make more economical investment decisions. Sustainability aspects in pavement management became an emergent issue, increasing their presence in publications.

Pavement performance modeling continued to be a major research area since local calibration of mechanical empirical models must be carried out, after having switched from mechanical modeling. Other models, such HDM-4 models, or their adaptations, were still applied in different countries with varying success.

Lastly, although data collection became almost fully automated, there were technological implementations, especially in cracking classifying methods and tools. The rolling wheel deflectometer received much attention, and it was applied to the assessment of structural indices.

Author Contributions: Conceptualization, H.P.-A., A.L.-U. and R.A.; Methodology, H.P.-A. and R.A.; Software, H.P.-A., A.L.-U. and R.A.; Validation, H.P.-A., R.A., A.L.-U. and E.R.; Formal Analysis, H.P.-A., A.L.-U. and E.R.; Investigation, H.P.-A. and R.A.; Resources, A.L.-U. and E.R.; Data Curation, H.P.-A., R.A. and A.L.-U.; Writing-Original Draft Preparation, H.P.-A., R.A., A.L.-U. and E.R.; Writing-Review \& Editing, H.P.-A., R.A., A.L.-U. and E.R.; Visualization, A.L.-U.; Supervision, H.P.-A.; Project Administration, H.P.-A. and A.L.-U.; Funding Acquisition, H.P.-A., A.L, R.A. and E.R.

Funding: This research was funded by Erasmus Mundus Action 2 ACTIVE “Atlantic Caucasus Technical universities Initiative for Valuable Education" programme grant number 2013-2523/001-001 EMA2; by Education Council of the Castille and Leon Government of Spain (Junta de Castilla y León) grant number BU0009A06 and UB 07/03, by Spanish Ministry of Economy and Competitiveness (MINECO) grant number CTQ2014-56820-JIN Project, co-financed by FEDER funds from European Union and by Basque Government grant number IT781-13.

Conflicts of Interest: The authors declare no conflict of interest. 


\section{References}

1. Xiong, H.; Shi, Q.; Tao, X.; Wang, W. A Compromise programming model for highway maintenance resources allocation problem. Math. Probl. Eng. 2012. [CrossRef]

2. Lee, E.-B.; Thomas, D.; Alleman, D. Incorporating road user costs into integrated life-cycle cost analyses for infrastructure sustainability: A case study on Sr-91 corridor improvement project (Ca). Sustainability 2018, 10, 179. [CrossRef]

3. ASCE. Report Card for America's Infrastructure. Advisory Council; American Society of Civil Engineers (ASCE): Washington, DC, USA, 2013.

4. AASHTO. Pavement Management Guide, 2nd ed.; American Association of State Highway and Transportation Officials (AASHTO): Washington, DC, USA, 2012.

5. Ho, Y.S. Bibliometric analysis of biosorption technology in water treatment research from 1991 to 2004. Int. J. Environ. Pollut. 2008, 34, 1-13. [CrossRef]

6. Xie, S.; Zhang, J.; Ho, Y.-S. Assessment of world aerosol research trends by bibliometric analysis. Scientometrics 2008, 77, 113-130. [CrossRef]

7. Zhang, G.; Xie, S.; Ho, Y.-S. A bibliometric analysis of world volatile organic compounds research trends. Scientometrics 2010, 83, 477-492. [CrossRef]

8. Fu, H.Z.; Ho, Y.S.; Sui, Y.M.; Li, Z.S. A bibliometric analysis of solid waste research during the period 1993-2008. Waste Manag. 2010, 30, 2410-2417. [CrossRef] [PubMed]

9. Ho, Y.S. Top-cited articles in chemical engineering in science citation index expanded: A bibliometric analysis. Chin. J. Chem. Eng. 2012, 20, 478-488. [CrossRef]

10. Chen, H.; Ho, Y.-S. Highly cited articles in biomass research: A bibliometric analysis. Renew. Sustain. Energy Rev. 2015, 49, 12-20. [CrossRef]

11. Franceschini, S.; Faria, L.G.D.; Jurowetzki, R. Unveiling scientific communities about sustainability and innovation. A bibliometric journey around sustainable terms. J. Clean. Prod. 2016, 127, 72-83. [CrossRef]

12. Bugge, M.; Hansen, T.; Klitkou, A. What is the bioeconomy? A review of the literature. Sustainability 2016, 8, 691. [CrossRef]

13. Wang, Z.; Chen, Y.; Cai, G.; Jiang, Z.; Liu, K.; Chen, B.; Jiang, J.; Gu, H. A bibliometric analysis of PubMed literature on middle east respiratory syndrome. Int. J. Environ. Res. Public Health 2016, 13, 583. [CrossRef] [PubMed]

14. Abejón, R.; Pérez-Acebo, H.; Garea, A. A bibliometric analysis of research on supported ionic liquid membranes during the 1995-2015 period: Study of the main applications and trending topics. Membranes 2017, 7, 63. [CrossRef] [PubMed]

15. Viana, J.; Santos, J.; Neiva, R.; Souza, J.; Duarte, L.; Teodoro, A.; Freitas, A. Remote sensing in human health: A 10-year Bibliometric analysis. Remote Sens. 2017, 9, 1225. [CrossRef]

16. Yang, G.; Wu, L. Trend in H2S biology and medicine research-A bibliometric analysis. Molecules 2017, $22,2087$. [CrossRef] [PubMed]

17. Albort-Morant, G.; Henseler, J.; Leal-Millán, A.; Cepeda-Carrión, G. Mapping the field: A bibliometric analysis of green innovation. Sustainability 2017, 9, 1011. [CrossRef]

18. Chen, H.; Jiang, W.; Yang, Y.; Yang, Y.; Man, X. State of the art on food waste research: A bibliometrics study from 1997 to 2014. J. Clean. Prod. 2017, 140, 840-846. [CrossRef]

19. Geng, Y.; Chen, W.; Liu, Z.; Chiu, A.S.F.; Han, W.; Liu, Z.; Zhong, S.; Qian, Y.; You, W.; Cui, X. A bibliometric review: Energy consumption and greenhouse gas emissions in the residential sector. J. Clean. Prod. 2017, 159, 301-316. [CrossRef]

20. Mejia, C.; Kajikawa, Y. Bibliometric analysis of social robotics research: Identifying research trends and knowledgebase. Appl. Sci. 2017, 7, 1316. [CrossRef]

21. Naveau, A.; Smirani, R.; Catros, S.; de Oliveira, H.; Fricain, J.-C.; Devillard, R. A bibliometric study to assess bioprinting evolution. Appl. Sci. 2017, 7, 1331. [CrossRef]

22. Hu, K.; Qi, K.; Guan, Q.; Wu, C.; Yu, J.; Qing, Y.; Zheng, J.; Wu, H.; Li, X. A scientometric visualization analysis for night-time light remote sensing research from 1991 to 2016. Remote Sens. 2017, 9, 802. [CrossRef]

23. Nie, B.; Sun, S. Using text mining techniques to identify research trends: A case study of design research. Appl. Sci. 2017, 7, 401. [CrossRef] 
24. Marx, W.; Haunschild, R.; Bornmann, L. The role of climate in the collapse of the maya civilization: A bibliometric analysis of the scientific discourse. Climate 2017, 5, 88. [CrossRef]

25. Gimenez, E.; Manzano-Agugliaro, F. DNA damage repair system in plants: A worldwide research update. Genes 2017, 8, 299. [CrossRef] [PubMed]

26. Mehmood, A.; On, B.W.; Lee, I.; Choi, G. Prognosis essay scoring and article relevancy using multi-text features and machine learning. Symmetry 2017, 9, 11. [CrossRef]

27. Abejón, R. A bibliometric study of scientific publications regarding hemicellulose valorization during the 2000-2016 Period: Identification of alternatives and hot topics. ChemEngineering 2018, 2, 7. [CrossRef]

28. Tang, M.; Liao, H.; Wan, Z.; Herrera-Viedma, E.; Rosen, M. Ten years of sustainability (2009 to 2018): A bibliometric overview. Sustainability 2018, 10, 1655. [CrossRef]

29. Luo, J.; Ji, C.; Qiu, C.; Jia, F. Agri-food supply chain management: Bibliometric and content analyses. Sustainability 2018, 10, 1573. [CrossRef]

30. Sánchez-Cañizares, S.; Castillo-Canalejo, A.; Cabeza-Ramírez, L. Sustainable tourism in sensitive areas: Bibliometric characterisation and content analysis of specialised literature. Sustainability 2018, 10, 1525. [CrossRef]

31. Consentino, R.; Santos, M.; Matos, L.; Machado, J. Bibliometric analysis of traditional Chinese medicine scientific production between 1982 and 2016 Indexed in PubMed. Medicines 2018, 5, 41. [CrossRef] [PubMed]

32. Yang, L.; Wang, Q.; Bai, X.; Deng, J.; Hu, Y. Mapping of trace elements in coal and ash research based on a bibliometric analysis method spanning 1971-2017. Minerals 2018, 8, 89. [CrossRef]

33. Jia, F.; Jiang, Y. Sustainable global sourcing: A systematic literature review and bibliometric analysis. Sustainability 2018, 10, 595. [CrossRef]

34. Liao, H.; Tang, M.; Luo, L.; Li, C.; Chiclana, F.; Zeng, X.-J. A bibliometric analysis and visualization of medical big data research. Sustainability 2018, 10, 166. [CrossRef]

35. Velasco-Muñoz, J.; Aznar-Sánchez, J.; Belmonte-Ureña, L.; Román-Sánchez, I. Sustainable water use in agriculture: A review of worldwide research. Sustainability 2018, 10, 1084. [CrossRef]

36. Velasco-Muñoz, J.; Aznar-Sánchez, J.; Belmonte-Ureña, L.; López-Serrano, M. Advances in water use efficiency in agriculture: A bibliometric analysis. Water 2018, 10, 377. [CrossRef]

37. Klein, S.; Hage, J.J. Measurement, calculation, and normal range of the Ankle-Arm index: A bibliometric analysis and recommendation for standardization. Ann. Vasc. Surg. 2006, 20, 282-292. [CrossRef] [PubMed]

38. Chiu, W.T.; Ho, Y.S. Bibliometric analysis of tsunami research. Scientometrics 2007, 73, 3-17. [CrossRef]

39. Scopus. Scopus Content Coverage Guide; 02.16 Version; Elservier: Amsterdam, The Netherlands, 2016.

40. Burnham, J.F. Scopus database: A review. Biomed. Digit. Libr. 2006, 3, 1-8. [CrossRef] [PubMed]

41. Haas, R.; Hudson, W.R.; Falls, L.C. Pavement Asset Management; John Wiley \& Sons, Inc.: Hoboken, NJ, USA, 2015.

42. Uddin, W. Pavement management systems. In The Handbook of Highway Engineering; Fwa, T.F., Ed.; Taylor \& Francis: Boca Raton, FL, USA, 2006.

43. Hu, J.; Ma, Y.; Zhang, L.; Gan, F.; Ho, Y.S. A historical review and bibliometric analysis of research on lead in drinking water field from 1991 to 2007. Sci. Total Environ. 2010, 408, 1738-1744. [CrossRef] [PubMed]

44. Yi, H.; Jie, W. A bibliometric study of the trend in articles related to eutrophication published in Science Citation Index. Scientometrics 2011, 89, 919. [CrossRef]

45. Abejón, R.; Garea, A. A bibliometric analysis of research on arsenic in drinking water during the 1992-2012 period: An outlook to treatment alternatives for arsenic removal. J. Water Process Eng. 2015, 6, 105-119. [CrossRef]

46. Garfield, E. The English language: The lingua franca of international science. Scientist 1989, 3, 12-13.

47. Tardy, C. The role of English in scientific communication: Lingua franca or Tyrannosaurus Rex? J. Engl. Acad. Purp. 2004, 3, 247-269. [CrossRef]

48. Durmuşoğlu, A. A pre-assessment of past research on the topic of environmental-friendly electronics. J. Clean. Prod. 2016, 129, 305-314. [CrossRef]

49. Makhoba, X.; Pouris, A. Bibliometric analysis of the development of nanoscience research in South Africa. S. Afr. J. Sci. 2017, 113. [CrossRef]

50. Li, N.; Han, R.; Lu, X. Bibliometric analysis of research trends on solid waste reuse and recycling during 1992-2016. Resour. Conserv. Recycl. 2018, 130, 109-117. [CrossRef]

51. Wang, Q.; Yang, Z.; Yang, Y.; Long, C.; Li, H. A bibliometric analysis of research on the risk of engineering nanomaterials during 1999-2012. Sci. Total Environ. 2014, 473, 483-489. [CrossRef] [PubMed] 
52. Wang, J.; Chen, Z.; Yang, L.; Xi, S. Study on trends and performance of landfill research from 1999 to 2013 by using bibliometric analysis. Environ. Prog. Sustain. Energy 2015, 34, 1349-1355. [CrossRef]

53. Ward, T.A.; Rezadad, M.; Fearday, C.J.; Viyapuri, R. A review of biomimetic air vehicle research: 1984-2014. Int. J. Micro Air Veh. 2015, 7, 375-394. [CrossRef]

54. Cañas-Guerrero, I.; Mazarrón, F.R.; Pou-Merina, A.; Calleja-Perucho, C.; Suárez-Tejero, M.F. Analysis of research activity in the field "Engineering, Civil" through bibliometric methods. Eng. Struct. 2013, 56, 2273-2286. [CrossRef]

55. Dimas de Castro e Silva, N.; Carlos Oliveira, C.; Fernanda, R.; Paulo, S. Bibliometric analysis of PPP and PFI literature: Overview of 25 years of research. J. Constr. Eng. Manag. 2016, 142. [CrossRef]

56. Salas, M.Á.; Pérez-Acebo, H.; Calderón, V.; Gonzalo-Orden, H. Bitumen modified with recycled polyurethane foam for employment in hot mix asphalt. Ing. Investig. 2018, 38, 60-66. [CrossRef]

57. Alyami, Z.; Farashah, M.K.; Tighe, S.L. Selection of automated data collection technologies using multi criteria decision making approach for pavement management systems. In Proceedings of the Annual Conference of the Canadian Society for Civil Engineering, 2012: Leadership in Sustainable Infrastructure, Montreal, QC, Canada, 5-8 June 2012; Canadian Society for Civil Engineering (CSCE): Montreal, QC, Canada, 2012; pp. 1712-1721.

58. Park, K.; Thomas, N.E.; Lee, K.W. Applicability of the international roughness index as a predictor of asphalt pavement condition1. J. Transp. Eng. 2007, 133, 706-709. [CrossRef]

59. AASHTO. AASHTO Guide for Design of Pavement Structures; American Association of State Highway and Transportation Officials (AASHTO): Washington, DC, USA, 1993.

60. Pérez-Acebo, H.; Gonzalo-Orden, H.; Rojí, E. Skid resistance prediction for new two-lane roads. Proc. Inst. Civ. Eng. Transp. 2017. [CrossRef]

61. Huang, Y.; Copenhaver, T.; Hempel, P.; Mikhail, M. Development of texture measurement system based on continuous profiles from three-Dimensional scanning system. Transp. Res. Rec. J. Transp. Res. Board 2013, 2367, 13-22. [CrossRef]

62. Laurent, J.; Hébert, J.F.; Lefebvre, D.; Savard, Y. High-speed network level road texture evaluation using $1 \mathrm{~mm}$ resolution transverse 3D profiling sensors using a digital sand patch model. In Proceedings of the 7th International Conference on Maintenance and Rehabilitation of Pavements and Technological Control, Auckland, New Zealand, 28-30 August 2012; University of Auckland: Auckland, New Zealand, 2012.

63. Huang, Y.; Copenhaver, T.; Hempel, P. Texas department of transportation 3D transverse profiling system for high-speed rut measurement. J. Infrastruct. Syst. 2013, 19, 221-230. [CrossRef]

64. Meegoda, J.N.; Gao, S.; Liu, S.; Gephart, N.C. Pavement texture from high-speed laser for pavement management system. Int. J. Pavement Eng. 2013, 14, 697-705. [CrossRef]

65. Rajapakshe, M.; Fuentes, L.G.; Gunaratne, M. Using the ASTM E 274 skid trailer data to characterize pavement friction behavior with respect to the traveling speed and the wheel slip ratio. Dyna-Colombia 2012, 79, 130-138.

66. Lee, J.; Lee, J.; Kim, Y.; Mun, S. A comparison study of friction measurements for chip seal. J. Test. Eval. 2012, 40, 1-9. [CrossRef]

67. Kodippily, S.; Henning, T.F.P.; Ingham, J.M. Detecting flushing of thin-sprayed seal pavements using pavement management data. J. Transp. Eng. 2012, 138, 665-673. [CrossRef]

68. Adarkwa, O.A.; Attoh-Okine, N. Pavement crack classification based on tensor factorization. Constr. Build. Mater. 2013, 48, 853-857. [CrossRef]

69. Saarenketo, T.; Matintupa, A.; Varin, P. The use of ground penetrating radar, thermal camera and laser scanner technology in asphalt crack detection and diagnostics. In Proceedings of the 7th RILEM International Conference on Cracking in Pavements, Delft, The Netherlands, 20-22 June 2012; Springer: Dordrecht, The Netherlands, 2012; pp. 137-145. [CrossRef]

70. Jahanshahi, M.; Jazizadeh, F.; Masri, S.; Becerik-Gerber, B. A novel system for road surface monitoring using an inexpensive infrared laser sensor. In Proceedings of the Sensors and Smart Structures Technologies for Civil, Mechanical and Aerospace Systems, San Diego, CA, USA, 12-15 March 2012; SPIE-International Society for Optics and Photonics: Bellingham, WA, USA, 2012; pp. 20-26. [CrossRef]

71. Santhi, B.; Krishnamurthy, G.; Siddharth, S.; Ramakrishnan, P.K. Automatic detection of cracks in pavements using edge detection operator. J. Theor. Appl. Inf. Technol. 2012, 36, 199-205. 
72. Vallejo, L.E. Fractal evaluation of the level of alligator cracking in pavements. Geomech. Eng. 2012, 4, $219-227$. [CrossRef]

73. Tang, J.; Sun, B. An integrated digital image processing pavement management information system. In Proceedings of the ICLEM 2012: Logistics for Sustained Economic Development-Technology and Management for Efficiency, Chengdu, China, 8-10 October 2012; American Society of Civil Engineers (ASCE): Chengdu, China, 2012. [CrossRef]

74. Li, L.; Sun, L.J.; Tan, S.G.; Ning, G.B. An efficient way in image preprocessing for pavement crack images. In Proceedings of the 12th COTA International Conference of Transportation Professionals: Multimodal Transportation Systems-Convenient, Safe, Cost-Effective, Efficient, Beijing, China, 3-6 August 2012; American Society of Civil Engineers (ASCE): Beijing, China, 2012; pp. 3095-3103. [CrossRef]

75. Laurent, J.; Hébert, J.F.; Lefebvre, D.; Savard, Y. Using 3D Laser profiling sensors for the automated measurement of road surface conditions. In Proceedings of the 7th RILEM International Conference on Cracking in Pavements, Delft, The Netherlands, 20-22 June 2012; Springer: Dordrecht, The Netherlands, 2012; pp. 157-167. [CrossRef]

76. Sayers, M.W.; Gillespie, T.D.; Paterson, W.D. Guidelines for Conducting and Calibrating Rod Roughness Measurements; Technical Paper Number 46; The Word Bank: Washington, DC, USA, 1986.

77. Pérez-Acebo, H.; Mindra, N.; Railean, A.; Rojí, E. Rigid pavement performance models by means of Markov Chains with half-year step time. Int. J. Pavement Eng. 2017, 1-14. [CrossRef]

78. Pérez-Acebo, H.; Bejan, S.; Gonzalo-Orden, H. Transition probability matrices for flexible pavement deterioration models with half-year cycle time. Int. J. Civ. Eng. 2017. [CrossRef]

79. Wang, H.; Chen, Z.; Sun, L. Pavement roughness evaluation for urban road management. In Proceedings of the 4th International Conference on Transportation Engineering, Chengdu, China, 19-20 October 2013; American Society of Civil Engineers (ASCE): Chengdu, China, 2013; pp. 2709-2713. [CrossRef]

80. Shahnazari, H.; Tutunchian, M.A.; Mashayekhi, M.; Amini, A.A. Application of soft computing for prediction of pavement condition index. J. Transp. Eng. 2012, 138, 1495-1506. [CrossRef]

81. Mahmood, M.; Rahman, M.; Nolle, L.; Mathavan, S. A fuzzy logic approach for pavement section classification. Int. J. Pavement Res. Technol. 2013, 6, 620-626. [CrossRef]

82. Bejan, S.; Pérez-Acebo, H. Modeling the dynamic interaction between a vibratory-compactor and ground. Rom. J. Acoust. Vib. 2016, 12, 94-97.

83. Markó, G.; Primusz, P.; Péterfalvi, J. Measuring the bearing capacity of forest roads with an improved benkelman beam apparatus. Acta Silv. Lignaria Hung. 2013, 9, 97-109. [CrossRef]

84. Korczak, R.; Tighe, S.; Cimini, G. Use of an Automated Temperature Data Logger (ATDL) during Falling Weight Deflectometer (FWD) Testing. In Proceedings of the 2012 Annual Conference of the Transportation Association of Canada: Innovations and Opportunities, Ottawa, ON, Canada, 14-17 October 2012; Transportation Association of Canada (TAC): Ottawa, ON, Canada, 2012.

85. Elseifi, M.A.; Abdel-Khalek, A.M.; Gaspard, K.; Zhang, Z.; Ismail, S. Evaluation of continuous deflection testing using the rolling wheel deflectometer in Louisiana. J. Transp. Eng. 2012, 138, 414-422. [CrossRef]

86. Gaspard, K.; Zhang, Z.; Elseifi, M.A. Integration of rolling wheel deflectometer deflection measurements into pavement management systems. Transp. Res. Rec. J. Transp. Res. Board 2013, 2366, 25-33. [CrossRef]

87. Prang, C.; Podborochynski, D.; Kelln, R.; Berthelot, C. City of Saskatoon's pavement management system: Network level structural evaluation. In Proceedings of the 2012 Annual Conference of the Transportation Association of Canada: Innovations and Opportunities, Ottawa, ON, Canada, 14-17 October 2012; Transportation Association of Canada (TAC): Ottawa, ON, Canada, 2012.

88. Zaghloul, S.; He, Z.; Vitillo, N.; Kerr, J. Project scoping using falling weight deflectometer testing: New Jersey experience. Transp. Res. Rec. 1998, 1643, 34-43. [CrossRef]

89. Bryce, J.; Flintsch, G.; Katicha, S.; Diefenderfer, B. Enhancing network-level decision making through the use of a structural capacity index. Transp. Res. Rec. J. Transp. Res. Board 2013, 2366, 64-70. [CrossRef]

90. Carvalho, R.; Stubstad, R.; Wiser, L.; Selezneva, O. Simplified deflection-based probabilistic technique for network-level pavement analysis. In Pavement Performance: Current Trends, Advances, and Challenges; ASTM International: West Conshohocken, PA, USA, 2012; pp. 170-191.

91. Bryce, J.; Flintsch, G.; Katicha, S.; Diefenderfer, B. Developing a network-level structural capacity index for asphalt pavements. J. Transp. Eng. 2013, 139, 123-129. [CrossRef] 
92. Elseifi, M.A.; Dasari, K.; Abdel-Khalek, A.M.; Gaspard, K.; Zhang, Z. Development of the triangular model for pavement evaluation using the rolling wheel deflectometer. J. Transp. Eng. 2013, 139, 313-320. [CrossRef]

93. Sunitha, V.; Amirthalingam, V.; Srinivasan, K.; Mathew, S. Application of factor analysis in maintenance management of low volume roads. Int. J. Pavement Res. Technol. 2013, 6, 130-135. [CrossRef]

94. Nam, B.H.; Murphy, M.; Zhang, Z.; Arellano, M. Improved Structural condition index for pavement evaluation at network level. In Proceedings of the Airfield and Highway Pavement 2013: Sustainable and Efficient Pavements, Los Angeles, CA, USA, 9-12 June 2013; ASCE: Los Angeles, CA, USA, 2013; pp. 781-790. [CrossRef]

95. Bianchini, A. Fuzzy representation of pavement condition for efficient pavement management. Comput. Aided Civ. Infrastruct. Eng. 2012, 27, 608-619. [CrossRef]

96. Zhao, H.; Lea, J.; Harvey, J.T.; Lea, J. Pavement structure segmentation method based on results derived from ground-penetrating radar data. Int. J. Pavement Eng. 2013, 14, 333-342. [CrossRef]

97. Wang, Z.; Tsai, Y. Pavement layer data repository using a spatiotemporal block model. J. Comput. Civ. Eng. 2013, 27, 18-26. [CrossRef]

98. Saliminejad, S.; Gharaibeh, N.G. Clustering pavement condition data based on spatiotemporal patterns. In Proceedings of the Airfield and Highway Pavement 2013: Sustainable and Efficient Pavements, Los Angeles, CA, USA, 9-12 June 2013; American Society of Civil Engineers (ASCE): Los Angeles, CA, USA, 2013. [CrossRef]

99. Gallegos, A.; Chang-Albitres, C.M.; Nazarian, S. Hybrid technique for calibrating network-level performance models of continuously reinforced concrete pavements. J. Transp. Eng. 2013, 139, 1194-1200. [CrossRef]

100. Retherford, J.Q.; McDonald, M. Unified approach for uncertainty analysis using the AASHTO mechanisticempirical pavement design guide. J. Transp. Eng. 2012, 138, 657-664. [CrossRef]

101. AASHTO. Guide for Mechanistic-Empirical Design of New and Rehabilitated Pavement Structures; NCHRP 1-37A; American Association of State Highway and Transportation Officials (AASHTO): Washington, DC, USA, 2004.

102. AASHTO. Mechanistic-Empirical Pavement Design Guide: A Manual of Practice; American Association of State Highway and Transportation Officials (AASHTO): Washington, DC, USA, 2008.

103. Waseem, A.; Yuan, X.X. Longitudinal local calibration of MEPDG permanent deformation models for reconstructed flexible pavements using PMS data. Int. J. Pavement Res. Technol. 2013, 6, 304-312. [CrossRef]

104. Meneses, S.; Ferreira, A. Pavement maintenance programming considering two objectives: Maintenance costs and user costs. Int. J. Pavement Eng. 2013, 14, 206-221. [CrossRef]

105. Meneses, S.; Ferreira, A.; Collop, A. Multi-objective decision-aid tool for pavement management. Proc. Inst. Civ. Eng. Transp. 2013, 166, 79-94. [CrossRef]

106. Banerjee, A.; Aguiar-Moya, J.; Prozzi, J. Calibration of mechanistic-empirical pavement design guide permanent deformation models. Transp. Res. Rec. 2009, 2094, 12-20. [CrossRef]

107. Li, J.; Pierce, L.; Uhlmeyer, J. Calibration of flexible pavement in mechanistic-empirical pavement design guide for Washington State. Transp. Res. Rec. 2009, 2095, 73-83. [CrossRef]

108. AASHTO. Guide for the Local Calibration of the Mechanistic-Empirical Pavement Design Guide; American Association of State Highway and Transportation Officials (AASHTO): Washington, DC, USA, 2010.

109. Von Quintus, H.L.; Darter, M.I.; Mallela, J. Recommended Practice for Local Calibration of the M-E Pavement Design Guide, National Cooperative Highway Research Program Project 1-40B Manual of Practice; Transportation Research Board, National Research Council: Washington, DC, USA, 2009.

110. Yuan, X.X.; Shehata, M.; Li, N. Review and verification of pavement distress models in MTO PMS2 based on in-service pavements data. Proc. Annu. Conf. Can. Soc. Civ. Eng. 2012, 2, 1692-1701.

111. Wu, Z.; Yang, X. Evaluation of the MEPDG Permanent Deformation Models in Louisiana Conditions. In Proceedings of the GeoCongress 2012, State of the Art and Practice in Geotechnical Engineering, Oakland, CA, USA, 25-29 March 2012; American Society of Civil Engineers (ASCE): New York, NY, USA, 2012; pp. 1438-1447. [CrossRef]

112. Yang, X.; Wu, Z. Effects of subgrade resilient modulus and climate inputs on MEPDG. In Proceedings of the GeoCongress 2012, State of the Art and Practice in Geotechnical Engineering, Oakland, CA, USA, 25-29 March 2012; American Society of Civil Engineers (ASCE): New York, NY, USA, 2012; pp. 1448-1457. [CrossRef]

113. Wu, Z.; Yang, X.; Zhang, Z. Evaluation of MEPDG flexible pavement design using pavement management system data: Louisiana experience. Int. J. Pavement Eng. 2013, 14, 674-685. [CrossRef] 
114. Zhou, C.; Huang, B.; Shu, X.; Dong, Q. Validating MEPDG with Tennessee Pavement Performance Data. J. Transp. Eng. 2013, 139, 306-312. [CrossRef]

115. Nassiri, S.; Shafiee, M.H.; Bayat, A. Development of roughness prediction models using Alberta transportation's pavement management system. Int. J. Pavement Res. Technol. 2013, 6, 714-720. [CrossRef]

116. Retherford, J.Q.; McDonald, M. Permanent deformation predictive equations applicable to mechanistic-empirical flexible pavement design. J. Transp. Eng. 2013, 139, 1156-1163. [CrossRef]

117. Fwa, T.F.; Chan, W.T.; Hoque, K.Z. Multiobjective optimization for pavement maintenance programming. J. Transp. Eng. 2000, 126, 367-374. [CrossRef]

118. Hong, F.; Prozzi, J.A. Estimation of pavement performance deterioration using Bayesian approach. J. Infrastruct. Syst. 2006, 12, 77-86. [CrossRef]

119. Sathaye, N.; Madanat, S. A bottom-up solution for the multi-facility optimal pavement resurfacing problem. Transp. Res. B Meth. 2011, 45, 1004-1017. [CrossRef]

120. Nakat, Z.S.; Madanat, S.M. Stochastic duration modeling of pavement overlay crack initiation. J. Infrastruct. Syst. 2008, 14, 185-192. [CrossRef]

121. Marzouk, M.; Awad, E.; El-Said, M. An integrated tool for optimizing rehabilitation programs of highways pavement. Balt. J. Road Bridge Eng. 2012, 7, 297-304. [CrossRef]

122. Tabatabaee, N.; Ziyadi, M. Bayesian approach to updating Markov-based models for predicting pavement performance. Transp. Res. Rec. 2013, 2366, 34-42. [CrossRef]

123. Lethanh, N.; Adey, B.T. Use of exponential hidden Markov models for modelling pavement deterioration. Int. J. Pavement Eng. 2013, 14, 645-654. [CrossRef]

124. Thomas, O.; Sobanjo, J. Comparison of Markov chain and Semi-Markov models for crack deterioration on flexible pavements. J. Infrastruct. Syst. 2013, 19, 186-195. [CrossRef]

125. Lu, P.; Tolliver, D. Pavement treatment short-term effectiveness in IRI change using long-term pavement program data. J. Transp. Eng. 2012, 138, 1297-1302. [CrossRef]

126. Mariani, M.C.; Bianchini, A.; Bandini, P. Normalized truncated Levy walk applied to flexible pavement performance. Transp. Res. C 2012, 24, 1-8. [CrossRef]

127. Aktas, B.; Karasahin, M.; Tigdemir, M. Developing a macrotexture prediction model for chip seals. Constr. Build. Mater. 2013, 41, 784-789. [CrossRef]

128. Khattak, M.J.; Landry, C.; Veazey, J.; Zhang, Z. Rigid and composite pavement index-based performance models for network pavement management system in the state of Louisiana. Int. J. Pavement Eng. 2013, 14, 612-628. [CrossRef]

129. Abaza, O.A.; Mullin, A.P. Modeling of pavement deterioration in cold regions. In Proceedings of the 10th International Symposium on Cold Regions Development: Planning for Sustainable Cold Regions, Anchorage, AK, USA, 2-5 June 2013; American Society of Civil Engineers (ASCE): Anchorage, AK, USA, 2013; pp. 416-427. [CrossRef]

130. Shah, Y.U.; Jain, S.S.; Tiwari, D.; Jain, M.K. Analysis of flexible pavement serviceability using ANN for urban roads. In Proceedings of the Airfield and Highway Pavement 2013: Sustainable and Efficient Pavements, Los Angeles, CA, USA, 9-12 June 2013; American Society of Civil Engineers (ASCE): Los Angeles, CA, USA, 2013. [CrossRef]

131. Thube, D.T. Artificial Neural Network (ANN) based pavement deterioration models for low volume roads in India. Int. J. Pavement Res. Technol. 2012, 5, 115-120. [CrossRef]

132. Oladele, A.S. Improved Intelligent Pavement Performance (IIPP) modeling for Botswana District Gravel Road Networks. In Proceedings of the Airfield and Highway Pavement 2013: Sustainable and Efficient Pavements, Los Angeles, CA, USA, 9-12 June 2013; American Society of Civil Engineers (ASCE): Los Angeles, CA, USA, 2013; pp. 1358-1369. [CrossRef]

133. Ahmed, A.; Labi, S.; Li, Z.; Shields, T. Aggregate and disaggregate statistical evaluation of the performance-based effectiveness of long-term pavement performance specific pavement study-5 (LTPP SPS-5) flexible pavement rehabilitation treatments. Struct. Infrastruct. Eng. 2013, 9, 172-187. [CrossRef]

134. Luo, Z. Pavement performance modelling with an auto-regression approach. Int. J. Pavement Eng. 2013, 14, 85-94. [CrossRef]

135. Thube, D.T. Highway Development and Management Model (HDM-4): Calibration and adoption for low-volume roads in local conditions. Int. J. Pavement Eng. 2013, 14, 50-59. [CrossRef] 
136. Ferreira, A.; Micaelo, R.; Souza, R. Cracking models for use in pavement maintenance management. In Proceedings of the 7th RILEM International Conference on Cracking in Pavements, Delft, The Netherlands, 20-22 June 2012; Springer: Dordrecht, The Netherlands, 2012; pp. 429-439. [CrossRef]

137. Jorge, D.; Ferreira, A. Road network pavement maintenance optimisation using the HDM-4 pavement performance prediction models. Int. J. Pavement Eng. 2012, 13, 39-51. [CrossRef]

138. Mull, D.M.; Sitzabee, W.E. Paint pavement marking performance prediction model. J. Transp. Eng. 2012, 138, 618-624. [CrossRef]

139. Wu, Z.; Flintsch, G.; Ferreira, A.; de Picado-Santos, L. Framework for multiobjective optimization of physical highway assets investments. J. Transp. Eng. 2012, 138, 1411-1421. [CrossRef]

140. Irfan, M.; Khurshid, M.B.; Bai, Q.; Labi, S.; Morin, T.L. Establishing optimal project-level strategies for pavement maintenance and rehabilitation-A framework and case study. Eng. Opt. 2012, 44, 565-589. [CrossRef]

141. Farhan, J.; Fang Fwa, T. Evaluation of effects of priority preferences on optimal resource allocation in pavement management. Adv. Mater. Res. 2013, 723, 838-845. [CrossRef]

142. Lu, P.; Tolliver, D. Multiobjective pavement-preservation decision making with simulated constraint boundary programming. J. Transp. Eng. 2013, 139, 880-888. [CrossRef]

143. Chi, S.; Hwang, J.; Arellano, M.; Zhang, Z.; Murphy, M. Development of network-level project screening methods supporting the 4-year pavement management plan in Texas. J. Manag. Eng. 2013, 29, 482-494. [CrossRef]

144. Gurganus, C.F.; Gharaibeh, N.G. Project selection and prioritization of pavement preservation: Competitive approach. Transp. Res. Rec. 2012, 36-44. [CrossRef]

145. Golroo, A.; Tighe, S. Optimum genetic algorithm structure selection in pavement management. Asian J. Appl. Sci. 2012, 5, 327-341. [CrossRef]

146. Alyami, Z.; Tighe, S. Development of maintenance and rehabilitation program pavement assets under performance-based contracts. Transp. Res. Rec. 2013, 2361, 1-10. [CrossRef]

147. Di Mino, G.; Blasiis, M.; Di Noto, F.; Noto, S. An advanced pavement management system based on a Genetic Algorithm for a Motorway Network. In Proceedings of the 3rd Conference on Soft Computing Technology in Civil, Structural and Environmental Engineering, Cagliari, Italy, 3-6 September 2013; Civil-Comp. Press: Stirlingshire, UK, 2013. [CrossRef]

148. Fwa, T.F.; Farhan, J. Optimal multiasset maintenance budget allocation in highway asset management. J. Transp. Eng. 2012, 138, 1179-1187. [CrossRef]

149. Yeo, H.; Yoon, Y.; Madanat, S. Algorithms for bottom-up maintenance optimisation for heterogeneous infrastructure systems. Struct. Infrastruct. E 2013, 9, 317-328. [CrossRef]

150. Yang, J. Nested Markov decision framework for coordinating pavement improvement with capacity expansion. J. Transp. Eng. 2012, 138, 387-394. [CrossRef]

151. Amer, M.A. Development of an urban non-pavement management system. Aust. J. Basic Appl. 2012, 6, $298-304$.

152. El Hamil, A.A.; Sturm, H.; Skinner, M. Development of a pavement management and prioritization framework for three active municipal landfills. In Proceedings of the 2012 Annual Conference of the Transportation Association of Canada: Innovations and Opportunities, Ottawa, ON, Canada, 14-17 October 2012; Transportation Association of Canada (TAC): Ottawa, ON, Canada, 2012.

153. Uzarowski, L.; Moore, G.; Henderson, V. Instrumentation in Red Hill Valley Parkway Providing Data for Long Term Pavement Management. In Proceedings of the 2012 Annual Conference of the Transportation Association of Canada: Innovations and Opportunities, Ottawa, ON, Canada, 14-17 October 2012; Transportation Association of Canada (TAC): Ottawa, ON, Canada, 2012.

154. Kerali, H.G.; Odoki, J.B.; Stannard, E.E. Overview of HDM-4 (HDM-4 Volume 1); Association Mondiale de la Route/World Road Association (AIPCR/PIARC): Paris, France, 2006.

155. Zakaria, Z.; Ismail, S.; Yusof, A.M. Effectiveness of pavement management system and its effects to the closing of final account in construction project in Malaysia. J. Phys. Conf. Ser. 2013, 423, 12034-12044. [CrossRef]

156. Chen, Y.L.; Lin, J.D. The study of HDM-4 applied in Taiwan area national freeway maintenance and management. Adv. Mater. Res. 2013, 723, 923-930. [CrossRef]

157. Kim, D.; Chi, S.; Kim, J. Selecting network-level project sections for sustainable pavement management in Texas. Sustainability 2018, 10, 686. [CrossRef] 
158. FHWA. Life-Cycle Cost Analysis Primer; U.S. Dept. of Transportation, Federal Highway Administration, Office of Asset Management: Washington, DC, USA, 2002.

159. Santos, J.; Ferreira, A. Pavement design optimization considering costs and preventive interventions. J. Transp. Eng. 2012, 138, 911-923. [CrossRef]

160. Pittenger, D.M.; Gransberg, D. Performance-based life cycle cost analysis: A chip seal field test case study. In Proceedings of the 7th International Conference on Maintenance and Rehabilitation of Pavements and Technological Control, Auckland, New Zealand, 28-30 August 2012; University of Auckland: Auckland, New Zealand, 2012.

161. Chu, J.C.; Li, M.H.; Chen, S.C. Threshold-based maintenance optimization for pavement infrastructure using hybrid dynamic modeling. Adv. Mater. Res. 2013, 723, 931-939. [CrossRef]

162. Ferreira, A.; Santos, J.O. Life-cycle cost analysis system for pavement management at project level: Sensitivity analysis to the discount rate. Int. J. Pavement Eng. 2013, 14, 655-673. [CrossRef]

163. Xu, Y.; Tsai, Y.C. Financial consequences of delaying pavement rehabilitation: Case study using LTPP Data. J. Transp. Eng. 2012, 138, 975-982. [CrossRef]

164. Hoffmann, M.; Blab, R. A standardized life-cycle costing framework for flexible and rigid pavements in Austria. In Proceedings of the 3rd International Symposium on Life-Cycle Civil Engineering: Life-Cycle and Sustainability of Civil Infrastructure Systems, Vienna, Austria, 3-6 October 2012; CRC Press: Boca Raton, FL, USA, 2012; pp. 2131-2138.

165. IPPC. Climate Change 2007: Synthesis Report; Intergovernmental Panel on Climate Change (IPPC): Geneva, Switzerland, 2013.

166. Lutsey, N.; Sperling, D. Greenhouse gas mitigation supply curve for the United States for transport versus other sectors. Transp. Res. D Transp. Environ. 2009, 14, 222-229. [CrossRef]

167. Huang, Y.; Ning, Y.; Zhang, T.; Wu, J. Measuring carbon emissions of pavement construction in China. Sustainability 2016, 8, 723. [CrossRef]

168. Vaitkus, A.; Vorobjovas, V.; Tuminienè, F.; Gražulytė, J.; Čygas, D. Soft Asphalt and Double Otta Seal—SelfHealing Sustainable Techniques for Low-Volume Gravel Road Rehabilitation. Sustainability 2018, 10, 198. [CrossRef]

169. Babashamsi, P.; Md Yusoff, N.; Ceylan, H.; Md Nor, N.; Salarzadeh Jenatabadi, H. Sustainable development factors in pavement life-cycle: Highway/Airport Review. Sustainability 2016, 8, 248. [CrossRef]

170. Santero, N.J.; Masanet, E.; Horvath, A. Life-cycle assessment of pavements. Part I: Critical review. Resour. Conserv. Recycl. 2011, 55, 801-809. [CrossRef]

171. Giustozzi, F.; Crispino, M.; Flintsch, G. Multi-attribute life cycle assessment of preventive maintenance treatments on road pavements for achieving environmental sustainability. Int. J. Life Cycle Assess. 2012, 17, 409-419. [CrossRef]

172. Osorio, A.; Tighe, S.; Chamorro, A.; Videla, C. Sustainable urban pavement management framework: A Chilean case study. In Proceedings of the 2012 Annual Conference of the Canadian Society for Civil Engineering (CSCE 2012): Leadership in Sustainable Infrastructure, Edmonton, AB, Canada, 6-9 June 2012; Canadian Society for Civil Engineering (CSCE): Edmonton, AB, Canada, 2012; pp. 3424-3432.

173. Gühnemann, A.; Laird, J.J.; Pearman, A.D. Combining cost-benefit and multi-criteria analysis to prioritise a national road infrastructure programme. Transp. Policy 2012, 23, 15-24. [CrossRef]

174. Han, D.; Kobayashi, K. Criteria for the development and improvement of PMS models. KSCE J. Civ. Eng. 2013, 17, 1302-1316. [CrossRef]

175. Harvey, J.; Kendall, A.; Jones, D.J.; Wang, T. Life cycle assessment for local government pavements: What questions should we be addressing and how? In Proceedings of the Airfield and Highway Pavement 2013: Sustainable and Efficient Pavements, Los Angeles, CA, USA, 9-12 June 2013; American Society of Civil Engineers (ASCE): Los Angeles, CA, USA, 2013. [CrossRef]

176. Bardeesi, M.W.; Attallah, Y. Economic and environmental consideration for pavement management systems. Eur. Sci. J. 2015, 11, 127-135.

177. Yu, B.; Lu, Q.; Xu, J. An improved pavement maintenance optimization methodology: Integrating LCA and LCCA. Transp. Res. A Policy Pract. 2013, 55, 1-11. [CrossRef]

178. Gosse, C.A.; Smith, B.L.; Clarens, A.F. Environmentally preferable pavement management systems. J. Infrastruct. Syst. 2013, 19, 315-325. [CrossRef] 
179. Lidicker, J.; Sathaye, N.; Madanat, S.; Horvath, A. Pavement resurfacing policy for minimization of life-cycle costs and greenhouse gas emissions. J. Infrastruct. Syst. 2013, 19, 129-137. [CrossRef]

180. Faghih-Imani, A.; Amador-Jimenez, L. Toward sustainable pavement management: Incorporating environmental impacts of pavement treatments into a performance-based optimization. Transp. Res. Rec. 2013, 13-24. [CrossRef]

181. Jiao, Y.; Bowen, Z.; Siranc, H. Study on the application of a management system for pavement based on $\mathrm{iPad}$ terminal with GIS. Inf. Technol. J. 2012, 11, 520-523. [CrossRef]

182. Yang, C.C.; Lin, J.D. Establishment of pavement information decision management platform via cloud computing technology. Adv. Mater. Res. 2013, 723, 829-837. [CrossRef]

(C) 2018 by the authors. Licensee MDPI, Basel, Switzerland. This article is an open access article distributed under the terms and conditions of the Creative Commons Attribution (CC BY) license (http:/ / creativecommons.org/licenses/by/4.0/). 